\title{
Properties of Amaranth Flour With Functional Oat Products
}

\author{
George E. Inglett ${ }^{1}$, Diejun $\mathrm{Chen}^{1} \&$ Sean $\mathrm{Liu}^{1}$ \\ ${ }^{1}$ Functional Foods Research Unit, National Center for Agricultural Utilization Research, USDA, Agricultural \\ Research Service, 1815 N University Street, Peoria, IL 61604, USA \\ Mention of trade names or commercial products in this publication is solely for the purpose of providing specific \\ information and does not imply recommendation or endorsement by the U.S. Department of Agriculture. USDA \\ is an equal opportunity provider and employer. \\ Correspondence: George E. Inglett, USDA, Agricultural Research Service, National Center for Agricultural \\ Utilization Research, Functional Foods Research Unit, USA. Tel: 1-309-681-6363; Fax: 1-309-681-6685. E-mail: \\ George.Inglett@ars.usda.gov
}

Received: June 12, 2014 Accepted: July 9, 2014 Online Published: July 15, 2014

doi:10.5539/jfr.v3n6p1 URL: http://dx.doi.org/10.5539/jfr.v3n6p1

\begin{abstract}
Amaranth flour (Salvia hispanica L.), gluten free and rich in essential amino acids, was composited with oat functional products containing $\beta$-glucan known for lowering blood cholesterol and preventing heart disease. The objective of this research was to study the pasting and rheological properties of amaranth flour interacted with functional oat products using Rapid Visco Analyzer followed by an advanced rheometer. The initial peak viscosities of amaranth-Nutrim (oat bran hydrocolloids) and amaranth-OBC (oat bran concentrate) composites were increased with higher Nutrim and $\mathrm{OBC}$ contents. The final pasting viscosities of amaranth-OBC composites were increased significantly with higher OBC contents while amaranth-Nutrim composites showed colloidal gel properties similar to Nutrim. On other hand, amaranth interacted with oat bran concentrate displayed the highest rheological solid properties as elastic gels. Shear thinning properties were observed for all the interactions between amaranth flour and functional oat products. The improved water holding capacities were found for interacted compositions with Nutrim and oat bran concentrate compared to amaranth flour. These amaranth flour and oat products compositions demonstrated improved nutritional value and texture qualities for functional food applications.
\end{abstract}

Keywords: amaranth, oat, $\beta$-glucan, gluten-free, pasting, rheology

\section{Introduction}

Amaranth (Salvia hispanica L.) is a plant that has been cultivated for about 8,000 years. Amaranth grains contain about thirty percent more protein than cereals like rice, sorghum and rye (Macvean \& Pöll, 1997). Cooked amaranth grains contain a source of thiamine, niacin, riboflavin, and folate, and dietary minerals including calcium, iron, magnesium, phosphorus, zinc, copper, and manganese that are comparable to common grains such as wheat germ, oats and others (USDA Nutrient Database, 2014). Amaranth flour has an unusually rich source of the essential amino acid lysine that is low in other grains (Myers \& Putnam, 1998). It also contains vitamin E in similar amounts to olive oil (USDA Nutrient Database, 2014). Amaranth also contains a promising source of protein for those who are gluten sensitive because its protein does not contain gluten unlike the protein found in grains such as wheat and rye (USDA Nutrient Database, 2014). Amaranth has a valuable nutrient content for gluten-free diets compared to buckwheat, corn, millet, wild rice, oats and quinoa (Gallagher et al., 2004). The interest in grain amaranth was revived in the 1970s since it has gluten-free palatability. In addition, amaranth seed oil may be of benefit for those with hypertension and cardiovascular disease. Moreover, regular consumption reduces blood pressure and cholesterol levels while improving antioxidant status and some immune parameters (Czerwiński et al., 2004; Martirosyan et al., 2007) via its content of plant stanols and squalene (Alegbejo, 2013).

Amaranth flour has been evaluated as an additive to wheat flour. The different levels of amaranth flour were mixed with the wheat flour and baking ingredients that were fermented, molded, pan-proved and baked. The loaf volume decreased with increasing amount of amaranth grain flour. There were significant differences in the use of $15 \%$ amaranth flour in evaluated sensory qualities (Ayo, 2001). 
Oat products such as whole oat flour (WOF) and oat bran concentrate (OBC) contain $\beta$-glucan that has beneficial health effects on coronary heart disease prevention by reducing serum cholesterol and postprandial serum glucose levels (Klopfenstein, 1988). Oat products have the beneficial effect on gut health since oat grain fibre contributes to an increase in faecal bulk. Therefore, several oat hydrocolloids, including Nutrim, were developed from $\mathrm{OBC}$ using mechanical shearing and steam jet-cooking to increase the $\beta$-glucan content in oat products (Inglett, 2000; Inglett, 2011). In addition to $\beta$-glucans, oat phenolic and other antioxidant compounds also provide health benefits as demonstrated for oat and barley (Madhujith \& Shahidi, 2007; Inglett et al., 2011; Inglett \& Chen, 2012). Oat hydrocolloid products containing $\beta$-glucan have numerous functional food applications to reduce fat content and calories in a variety of foods (Lee et al., 2004); control the rheology and texture of food products (Rosell et al., 2001); modify starch gelatinization and retrogradation (Rojas et al., 1999; Lee et al., 2005); and also provide freezing/thawing stability (Lee et al., 2002). It was reported that a 5\% dispersion of Nutrim had the same consistency as coconut cream when used in several Thai desserts (Maneepun et al., 1998). In addition, fat in muffins and frozen desserts could be replaced with Nutrim, and the effect on their flavor and texture was evaluated (Warner \& Inglett, 2006). A recent study showed that shortening in cakes could be substituted up to $40 \%$ of Nutrim without loss of cake quality (Lee et al., 2004). Rheological and physical evaluation of jet-cooked oat bran has been studied in low calorie cookies by replacing $20 \%$ of the shortening with oat $\beta$-glucan hydrocolloids (Lee \& Inglett, 2006). The cookies containing C-Trim20, another oat hydrocolloid, exhibited reduced spreading characteristics and increased elastic properties compared with the control. The study suggested that the replacement should be limited to less than $50 \%$ of the substitute for butter and coconut cream in bakery products (Inglett et al., 2000).

Amaranth flour and oat products complement each other since amaranth grains are limited in some essential amino acids, such as leucine and threonine (Bressani et al., 1989; Kaufmann et al., 1990) that are abundant in oats (Pisarikova et al., 2006; University of Wisconsin \& University of Minnesota, 2011). Also, the oat components appear to be helpful in improving physical properties such as water holding capacity and viscosity (Inglett et al., 2014) since its viscosity and cohesion are fairly low for food applications. Thus, Nutrim, OBC, and WOF were used in this study to produce unique composites containing $\beta$-glucan in combination with amaranth's distinctive protein profile along with its gluten free properties. The objectives of this study were to provide useful information on the pasting and rheological properties of amaranth-oat composites for potential new functional food products with desirable texture and health benefits.

\section{Materials and Method}

\subsection{Preparation of Amaranth-Oat Composites}

Organic Gluten free amaranth flour certified by international certification services Inc. was purchased from Dakota Prairie Organic Flour Co. Harvey, ND, USA. Oat bran concentrate (OBC) was supplied by Quaker Oats, Chicago, IL, USA (Lot 18608408). Nutrim (Lot 35503475N170) was provided by VDF FutureCeuticals (Momence, IL, USA). Nutrim was prepared by steam jet-cooking OBC, sieving, and drum-drying (Inglett, 2000). Organic whole oat flour colloidal fine (WOF) was provided by Grain Millers (Eugene, OR, USA).

Amaranth flour was mixed with corresponding oat product by a KitchenAid mixer (St Joseph, MI, USA) for 2 min. The mixtures were passed a 20 mesh sieve followed by additional mixing in a mixer for $1 \mathrm{~min}$ to obtain the desired composites.

\subsection{Measurement of Water-Holding Capacity}

The water-holding capacities (WHC) of the oat-amaranth samples were determined according to a previous procedure with minor modifications (Ade-Omowaye et al., 2003). Each sample (2 g) was mixed with $25 \mathrm{~g}$ of distilled water and vigorously mixed using a vortex for $1 \mathrm{~min}$ for a homogenous suspension and then held for $2 \mathrm{~h}$, followed by centrifugation at $1,590 \mathrm{~g}$ for $10 \mathrm{~min}$. Each treatment was replicated twice. Water-holding capacity was calculated by the difference of water added and decanted water of sample on dry basis.

\subsection{Pasting Property Measurement}

The pasting properties of samples were evaluated using a Rapid Visco Analyzer (RVA-4, Perten Scientific, Springfield, IL, USA). Each sample (2.24 g d.b.) was made up to a total weight of $28 \mathrm{~g}$ with distilled water in a RVA canister $\left(80 \mathrm{~g} \mathrm{~kg}^{-1}\right.$ solids, w/w). The viscosity of the suspensions was monitored during the following heating and cooling stages. Suspensions were equilibrated at $50{ }^{\circ} \mathrm{C}$ for $1 \mathrm{~min}$, heated to $95{ }^{\circ} \mathrm{C}$ at a rate of $6.0{ }^{\circ} \mathrm{C} / \mathrm{min}$, maintained at $95^{\circ} \mathrm{C}$ for $5 \mathrm{~min}$, and cooled to $50^{\circ} \mathrm{C}$ at rate of $6.0^{\circ} \mathrm{C} / \mathrm{min}$, and held at $50{ }^{\circ} \mathrm{C}$ for $2 \mathrm{~min}$. For all test measurements, a constant paddle rotating speed $(160 \mathrm{rpm})$ was maintained throughout the entire analysis except for $920 \mathrm{rpm}$ in the first $10 \mathrm{~s}$ to disperse sample. Each sample was analyzed in duplicate. The 
results were expressed in Rapid Visco Analyser units (RVU, 1 RVU $=12$ centipoises).

\subsection{Rheological Measurements}

After samples from the RVA were cooled to $25^{\circ} \mathrm{C}$ and equilibrated, they were loaded on a rheometer (AR 2000, TA Instruments, New Castle, DE, USA) with a $4 \mathrm{~cm}$ diameter parallel stainless plate with $1 \mathrm{~mm}$ gap to the surface. The outer edge of the plate was sealed with a thin layer of mineral oil (Sigma Chemical Co., St Louis, MO, USA) to prevent dehydration during the test. All rheological measurements were carried out at $25^{\circ} \mathrm{C}$ using a water circulation system within $\pm 0.1^{\circ} \mathrm{C}$. A strain sweep experiment was conducted initially to determine the limits of linear viscoelasticity; then a frequency sweep test was carried out to obtain storage modulus $\left(G^{\prime}\right)$ and loss modulus $\left(\mathrm{G}^{\prime \prime}\right)$ at frequencies ranging from 0.1 to $10 \mathrm{rad} \mathrm{s}^{-1}$. A strain of $0.5 \%$, which was within the linear viscoelastic range, was used for the dynamic experiments. The steady shear viscosity of the paste was measured as a function of shear rates from 1 to $100 \mathrm{~s}^{-1}$. The steady shear measurements apply varying steady shear deformation on sample material, with magnitude of each deformation depending on user-specified shear rates. All rheological measurements for samples were performed in duplicate.

\subsection{Statistical Analysis}

Data from replicated samples were analyzed by SAS software using analysis of variance with Duncan's multiple comparison adjustment to determine significant differences $(P<0.05)$ between treatments (SAS Institute, 1999).

\section{Results and Discussion}

\subsection{Comparison of Amaranth Nutrition Contents With Oat, Wheat, Rice, and Corn}

Amaranth is higher in minerals (calcium, iron, phosphorus, potassium), vitamins (riboflavin, niacin, folate, vitamin A, vitamin E), and total polyunsaturated fatty acid than oat, wheat, rice, and corn. It is notable that amaranth is the only one that contains vitamin $\mathrm{C}$ among the products in table 1. Also, Amaranth contains more protein $(13.56 \mathrm{~g} / 100 \mathrm{~g})$ than any other gluten-free grain (USDA data base, 2014). This small ancient seed has endured the ages, as an important food source for early civilizations to its current resurgence as a highly nutritious gluten-free grain. The replacement of flour by $25 \%$ amaranth flour in gluten-free recipes could improve the nutritional value, the taste and texture of gluten free baked goods. On other hand, oat contains the highest protein, magnesium, zinc, thiamin, vitamin K, and total monounsaturated fatty acid among products in Table 1. Especially, vitamin $\mathrm{K}$ was not found in amaranth and rice. Vitamin $\mathrm{K}$ is a fat-soluble vitamin that the body stores in fat tissue and the liver. It is best known for its role in helping blood clot and bone health (University of Maryland Medical Center, 2013). Therefore, amaranth and oat will complement each other as a nutritious gluten free diet. 
Table 1. Comparisons of amaranth with oat, wheat, rice and corn*

\begin{tabular}{|c|c|c|c|c|c|c|}
\hline $\begin{array}{l}\text { Nutrient } \\
\text { (per 100g) }\end{array}$ & unit & $\begin{array}{l}\text { Amaranth } \\
\text { (uncooked) }\end{array}$ & $\begin{array}{l}\text { Oat } \\
\text { (whole) }\end{array}$ & $\begin{array}{l}\text { Wheat } \\
\text { (whole) }\end{array}$ & $\begin{array}{l}\text { Rice } \\
\text { (white) }\end{array}$ & $\begin{array}{l}\text { Corn } \\
\text { (yellow) }\end{array}$ \\
\hline \multicolumn{7}{|l|}{ Proximates } \\
\hline Water & $\mathrm{g}$ & 11.29 & 9.37 & 12.42 & 11.89 & 10.91 \\
\hline Energy & kcal & 371.00 & 371.00 & 332.00 & 366.00 & 361.00 \\
\hline Protein & $\mathrm{g}$ & 13.56 & 13.70 & 9.61 & 5.95 & 6.93 \\
\hline Total lipid (fat) & g & 7.02 & 6.87 & 1.95 & 1.42 & 3.86 \\
\hline Carbohydrate, by difference & g & 65.25 & 68.18 & 74.48 & 80.13 & 76.85 \\
\hline Fiber, total dietary & g & 6.70 & 9.40 & 13.10 & 2.40 & 7.30 \\
\hline Sugars, total & g & 1.69 & 1.42 & 1.02 & 0.12 & 0.64 \\
\hline \multicolumn{7}{|l|}{ Minerals } \\
\hline Calcium, $\mathrm{Ca}$ & $\mathrm{mg}$ & 159.00 & 47.00 & 33.00 & 10.00 & 7.00 \\
\hline Iron, $\mathrm{Fe}$ & $\mathrm{mg}$ & 7.61 & 4.64 & 3.71 & 0.35 & 2.38 \\
\hline Magnesium, $\mathrm{Mg}$ & $\mathrm{mg}$ & 248.00 & 270.00 & 117.00 & 35.00 & 93.00 \\
\hline Phosphorus, P & $\mathrm{mg}$ & 557.00 & 458.00 & 323.00 & 98.00 & 272.00 \\
\hline Potassium, $\mathrm{K}$ & $\mathrm{mg}$ & 508.00 & 358.00 & 394.00 & 76.00 & 315.00 \\
\hline Sodium, $\mathrm{Na}$ & $\mathrm{mg}$ & 4.00 & 3.00 & 3.00 & 0.00 & 5.00 \\
\hline Zinc, Zn & $\mathrm{mg}$ & 2.87 & 3.20 & 2.96 & 0.80 & 1.73 \\
\hline \multicolumn{7}{|l|}{ Vitamins } \\
\hline Vitamin C, total ascorbic acid & $\mathrm{mg}$ & 4.20 & 0.00 & 0.00 & 0.00 & 0.00 \\
\hline Thiamin & $\mathrm{mg}$ & 0.12 & 0.54 & 0.30 & 0.14 & 0.25 \\
\hline Riboflavin & $\mathrm{mg}$ & 0.20 & 0.12 & 0.19 & 0.02 & 0.08 \\
\hline Niacin & $\mathrm{mg}$ & 0.92 & 0.82 & 5.35 & 2.59 & 1.90 \\
\hline Vitamin B-6 & $\mathrm{mg}$ & 0.59 & 0.10 & 0.19 & 0.44 & 0.37 \\
\hline Folate, DFE & $\mu \mathrm{g}$ & 82.00 & 32.00 & 28.00 & 4.00 & 25.00 \\
\hline Vitamin B-12 & $\mu \mathrm{g}$ & & 0.00 & & & \\
\hline Vitamin A, RAE & $\mu \mathrm{g}$ & 0.00 & 0.00 & 0.00 & 0.00 & 11.00 \\
\hline Vitamin A, IU & $\mathrm{IU}$ & 2.00 & 0.00 & 9.00 & 0.00 & 214.00 \\
\hline Vitamin E (alpha-tocopherol) & $\mathrm{mg}$ & 1.19 & 0.70 & 0.53 & 0.11 & 0.42 \\
\hline Vitamin D (D2 + D3) & $\mu \mathrm{g}$ & 0.00 & 0.00 & 0.00 & 0.00 & 0.00 \\
\hline Vitamin D & IU & 0.00 & 0.00 & 0.00 & 0.00 & 0.00 \\
\hline Vitamin K (phylloquinone) & $\mu \mathrm{g}$ & 0.00 & 3.20 & 1.90 & 0.00 & 0.30 \\
\hline \multicolumn{7}{|l|}{ Lipids } \\
\hline Fatty acids, total saturated & g & 1.46 & 1.11 & 0.43 & 0.39 & 0.54 \\
\hline Fatty acids, total monounsaturated & g & 1.69 & 1.98 & 0.28 & 0.44 & 1.02 \\
\hline Fatty acids, total polyunsaturated & $\mathrm{g}$ & 2.78 & 2.30 & 1.17 & 0.38 & 1.76 \\
\hline Cholesterol & $\mathrm{mg}$ & 0.00 & 0.00 & 0.00 & 0.00 & 0.00 \\
\hline
\end{tabular}

*Data were selected from USDA Nutrient Database.

\subsection{Water-Holding Capacity}

The water-holding capacities (WHC) of the starting materials and their composites are shown in Table 2. Nutrim 
had the highest water-holding capacity (5993 $\mathrm{g} \mathrm{kg}^{-1}$ ) among all the samples tested. Nutrim was produced by jet-cooking technology using thermal-shearing forces to promote molecular breakdown that probably contributed to increased water absorption (Inglett, 2000; Lee \& Inglett, 2006). Overall, the WHC of amaranth-Nutrim composites $\left(1470 \mathrm{~g} \mathrm{~kg}^{-1}, 2450 \mathrm{~g} \mathrm{~kg}^{-1}, 4493 \mathrm{~g} \mathrm{~kg}^{-1}\right)$ were higher than that of amaranth-OBC $\left(1672 \mathrm{~g} \mathrm{~kg}^{-1}, 1939 \mathrm{~g}\right.$ $\left.\mathrm{kg}^{-1}, 2545 \mathrm{~g} \mathrm{~kg}^{-1}\right)$ and amaranth-WOF composites $\left(1314 \mathrm{~g} \mathrm{~kg}^{-1}, 1329 \mathrm{~g} \mathrm{~kg}^{-1}, 1476 \mathrm{~g} \mathrm{~kg}^{-1}\right)$ at the corresponding levels with the exclusion of amaranth-OBC 3:1. The WHC of amaranth composites with Nutrim and OBC were increased significantly with the increasing amount of the oat component (Table 2).

The $\beta$-glucan contents for WOF, OBC, and Nutrim were $40 \mathrm{~g} \mathrm{~kg}^{-1}, 120 \mathrm{~g} \mathrm{~kg}^{-1}$ and $150 \mathrm{~g} \mathrm{~kg}^{-1}$, respectively. The trend of WOF, OBC, and Nutrim water-holding capacity (Table 2, $1574 \mathrm{~g} \mathrm{~kg}^{-1}, 3559 \mathrm{~g} \mathrm{~kg}^{-1}, 5993 \mathrm{~g} \mathrm{~kg}^{-1}$ ) appeared to be related to their $\beta$-glucan contents, suggesting $\beta$-glucan may be an important factor for WHC. The WHC for all three composites were higher than amaranth flour alone with exceptions of amaranth-WOF 3:1 and 1:1. WHC for Amaranth-Nutrim 1:1 (2450 $\left.\mathrm{g} \mathrm{kg}^{-1}\right)$ was almost doubled while WHC for amaranth-Nutrim 1:3(4493 $\left.\mathrm{g} \mathrm{kg}^{-1}\right)$ was almost tripled compared with the amaranth flour alone $\left(1360 \mathrm{~g} \mathrm{~kg}^{-1}\right)$. Amaranth-oat composites could be widely used in different applications in the food industry because of their ability to retain water compared to amaranth flour alone, also notable for their thickening and gelling properties, syneresis control, and emulsion stabilization.

Table 2. Water holding capacity of amaranth, oat products, and oat-amaranth composites

\begin{tabular}{ll}
\hline Sample & $\begin{array}{l}\text { Water holding capacity } \\
\%\end{array}$ \\
\hline Amaranth & $136.64 \pm 0.50 \mathrm{hi}$ \\
Amaranth-Nutrim 3:1 & $147.03 \pm 1.31 \mathrm{gh}$ \\
Amaranth-Nutrim 1:1 & $245.04 \pm 0.57 \mathrm{~d}$ \\
Amaranth-Nutrim 1:3 & $449.27 \pm 11.53 \mathrm{~b}$ \\
Nutrim & $599.26 \pm 0.64 \mathrm{a}$ \\
Amaranth-OBC $3: 1$ & $167.23 \pm 9.65 \mathrm{f}$ \\
Amaranth-OBC 1:1 & $193.94 \pm 3.58 \mathrm{e}$ \\
Amaranth-OBC 1:3 & $254.52 \pm 3.58 \mathrm{~d}$ \\
OBC & $355.89 \pm 7.19 \mathrm{c}$ \\
Amaranth-WOF $3: 1$ & $131.43 \pm 1.64 \mathrm{i}$ \\
Amaranth-WOF 1:1 & $132.92 \pm 0.02 \mathrm{i}$ \\
Amaranth-WOF 1:3 & $147.62 \pm 7.28 \mathrm{gh}$ \\
WOF & $157.40 \pm 2.23 \mathrm{fg}$ \\
\hline
\end{tabular}

Means \pm standard deviation; $\mathrm{n}=3$; means followed by the same letter within the same column are not significantly different $(P>0.05)$.

\subsection{RVA Pasting Properties}

The pasting curves of the amaranth, oat products and their composites were obtained by RVA expressed as RVU (Rapid viscosity units, 1 RVU equal 12 centipoises). As shown in the Figure 1, the pasting curves of all samples had dissimilar patterns. In Fig.1a, the Nutrim pasting viscosity exhibited a sharply increased ( $23 \mathrm{RVU} / \mathrm{min})$ and significantly high $(\sim 250 \mathrm{RVU})$ peak during the initial $11 \mathrm{~min}$ heating period at $90{ }^{\circ} \mathrm{C}$ followed by a rapid decrease in viscosity to $(\sim 25 \mathrm{RVU})$ during continued heating, and a slight increase during cooling (final viscosity $58 \mathrm{RVU})$. It is known that the viscosity of a completely gelatinized starch slurry decreases during heating (Guha et al., 1998). These characteristics are common for pregelatinized flour (Lai \& Cheng, 2004) and typical for Nutrim since it had undergone jet-cooking during preparation where starch gelatinization occurred. The viscosity of OBC increased gradually $(\sim 7 \mathrm{RUV} / \mathrm{min})$ to the initial peak (100 RVU) after temperature reached $95{ }^{\circ} \mathrm{C}$, remained almost constant viscosity during heating, and then increased sharply ( 10 RVU/min) during cooling resulting in a considerably high final viscosity $(210 \mathrm{RVU})$. The viscosity of $\mathrm{OBC}$ increased during the heating and shearing possibly due to starch gelatinization and interaction with $\beta$-glucan in $\mathrm{OBC}$ resulted in an 
entanglement of molecules during cooling indicating the formation a matrix with greater stability under heat and shear. WOF had a lower viscosity peak $(\sim 50 \mathrm{RVU})$ than Nutrim and $\mathrm{OBC}$ at $95^{\circ} \mathrm{C}$, showing a small breakdown, and then slowly increased to a final viscosity ( $\sim 85 \mathrm{RVU})$ that was lower than OBC but higher than the rest of the starting materials. The viscosity of amaranth showed the initial peak $(\sim 50 \mathrm{RVU})$ at $95^{\circ} \mathrm{C}$, and then the viscosity are kept constant until reached a final viscosity ( $\sim 57 \mathrm{RVU})$ similar to Nutrim ( $\sim 60 \mathrm{RVU})$.

Amaranth-Nutrim-1:3, 1:1 and 3:1 had similar viscosity curve patterns to Nutrim (Figure 1b) showing initial peaks before reaching $95{ }^{\circ} \mathrm{C}$. However the initial peak viscosities of Amaranth-Nutrim-3:1 (50 RVU), 1:1(72 RVU) and 1:3(110 RVU) were lower than Nutrim probably because of a lower viscosity attributed by amaranth (Figure 1b). Furthermore, the initial peak viscosities of Amaranth-Nutrim-3:1, 1:1 and 1:3 were evidently increased with the increasing amount of Nutrim. On the other hand, all the amaranth-Nutrim composites displayed similar final viscosities compared with Nutrim and amaranth flour. It suggested that Amaranth -Nutrim composites would have similar viscosity properties to Nutrim after shearing and cooking

Similar viscosity patterns were observed for amaranth-OBC composites showing increased viscosities with the increased $\mathrm{OBC}$ contents in composites (Figure 1c). Over all, amaranth-OBC composites had higher final viscosities than amaranth-Nutrim (Figure 1b) and amaranth-WOF composites (Figure 1c) since the highest final viscosities during cooling were found for the OBC compared to Nutrim and WOF. It indicated that amaranth-OBC composites could be suitable for the products receiving heat and shear treatment. The initial and final peak viscosities of amaranth-WOF composites were low since both amaranth and WOF had low initial and final peak viscosities (Figure 1d). Amaranth-WOF 1:3 had the highest final viscosity ( $72 \mathrm{RVU})$, whereas WOF-amaranth $3: 1$ had the lowest final viscosity ( $\sim 54 \mathrm{RVU})$. Also, the initial viscosity peaks of amaranth-WOF composites were slightly delayed to 12 min compared to amaranth flour at $11 \mathrm{~min}$.

Improvement in the textural properties of food using oat $\beta$-glucan hydrocolloids has been reported so that the RVA data could provide useful information for food processing and product development (Lee et al., 2009). Composites having low viscosity may be suitable for products such as nutritional bars. Composites with high initial paste viscosity suggest their uses in food formulations such as beverages. For high viscosities of composites, they could be used for products such as breads, muffin, and cookies for improved the texture quality and health benefits. 

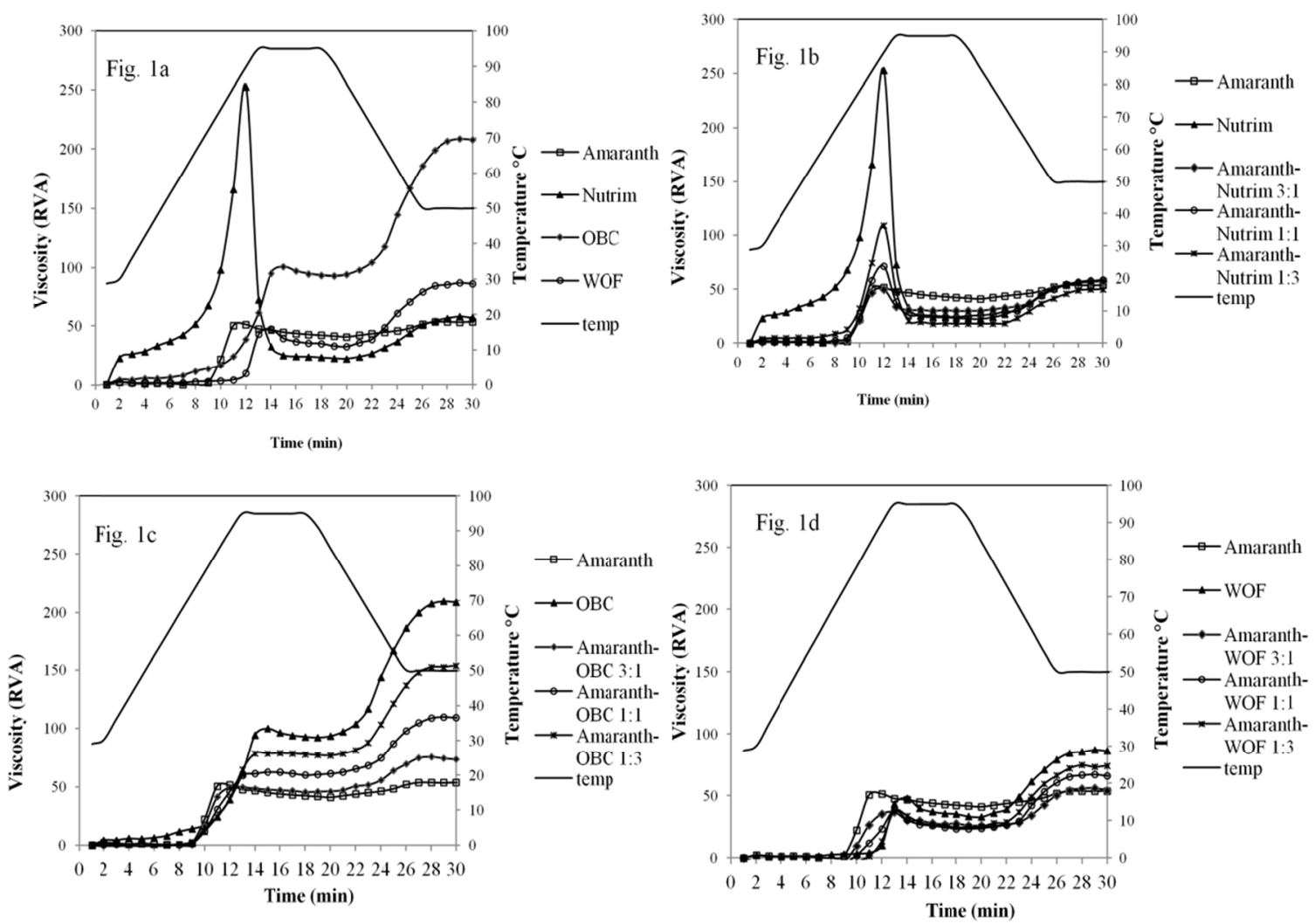

Figure 1. Rapid Visco-Analyser pasting curve of amaranth, oat products, and oat-amaranth composites

\subsection{Rheological Properties}

The dynamic viscoelastic properties have been related to the product quality. The $\mathrm{G}^{\prime}$ and $\mathrm{G}^{\prime \prime}$ against frequency for all the starting materials are displayed in Figure 2. The $\mathrm{G}^{\prime}$, an elastic (storage) modulus, represents the non-dissipative component of the mechanical properties of a material and reflects its elastic characteristics. On the other hand, the viscous (loss) modulus ( $\left.G^{\prime \prime}\right)$ characterizes the dissipative part of the mechanical properties and represents the viscous flow of the material. Both moduli ( $G^{\prime}$ and $\left.G^{\prime \prime}\right)$ of Nutrim showed frequency dependence, indicating the colloidal gel properties of Nutrim. In contrast, there were no significant changes with increasing frequencies for both moduli $\left(\mathrm{G}^{\prime}\right.$ and $\left.\mathrm{G}^{\prime \prime}\right)$ of other starting materials, indicating frequency independence. Moreover, elastic moduli $\mathrm{G}^{\prime}$ were greater than viscous $\mathrm{G}^{\prime \prime}$ throughout the frequency range (Figure 2a) for starting materials with different levels, implying more solid-like behaviors with the exception of Nutrim. Particularly, the large differences between $G^{\prime}$ and $G^{\prime \prime}$ were observed for OBC. Such results suggested a more viscous nature was predominant and the property of these materials could be classified rheologically as elastic gels (Lee \& Inglett, 2006; Lai \& Liao, 2002). The highest values between storage G' and loss G" moduli were observed for $\mathrm{OBC}$ followed by WOF. It may be contributed to the polysaccharides of OBC including amylose and amylopectin. Both $G^{\prime}$ and $G^{\prime \prime}$ for Nutrim gels were considerably lower than OBC and WOF probably due to the hydrothermal processing of Nutrim that resulted in the interactions of its amylose, amylopectin, and $\beta$-glucan components. The rheological trends of the starting materials were in agreement with the RVA data (Figure 1). Molecular weight for Nutrim at its peak was $3.0 \times 10^{5}$ that is smaller than OBC $\left(1.5 \times 10^{6}\right)$ as measured by a size-exclusion chromatography instruments (Shiamdzu, VP series, Tokyo, Japan) (Kim et al., 2008). Our rheological results showed a maximum value of dynamic storage modulus $G^{\prime}$ for Nutrim that was lower than OBC. It was in contrast with a previous report that the maximum value of dynamic storage modulus $\mathrm{G}^{\prime}$ decreased with increasing molecular size of the polysaccharides (Vaikousi et al., 2004). It may be due to the heating effect of $\mathrm{OBC}$ during the RVA test that could change carbohydrate bonds and influence molecular weight.

Both moduli ( $\mathrm{G}^{\prime}$ and $\left.\mathrm{G}^{\prime \prime}\right)$ of Nutrim composites showed more frequency-dependent than other samples (Figure $2 b$ ), indicating that the property of these materials could be classified as colloidal gels similar to Nutrim. The elastic 
moduli G' of amaranth-Nutrim composites were considerably lower than amaranth at low frequencies, and were close to amaranth flour at high frequency showing their colloidal gel properties. The $\mathrm{G}^{\prime}$ and $\mathrm{G}^{\prime \prime}$ from $\mathrm{OBC}$ were considerably higher than those from amaranth and its composites (Figure 2c), showing the larger differences between amaranth and it composites. There was slightly more frequency-dependence for amaranth-OBC composites compared to amaranth. It suggested that the colloidal gel properties of amaranth-OBC composites were improved by OBC. The differences between amaranth-WOF composites were smaller (Figure 2d) compared to $\mathrm{OBC}$ composites (Figure 2c) but larger than amaranth-Nutrim (Figure 2b).
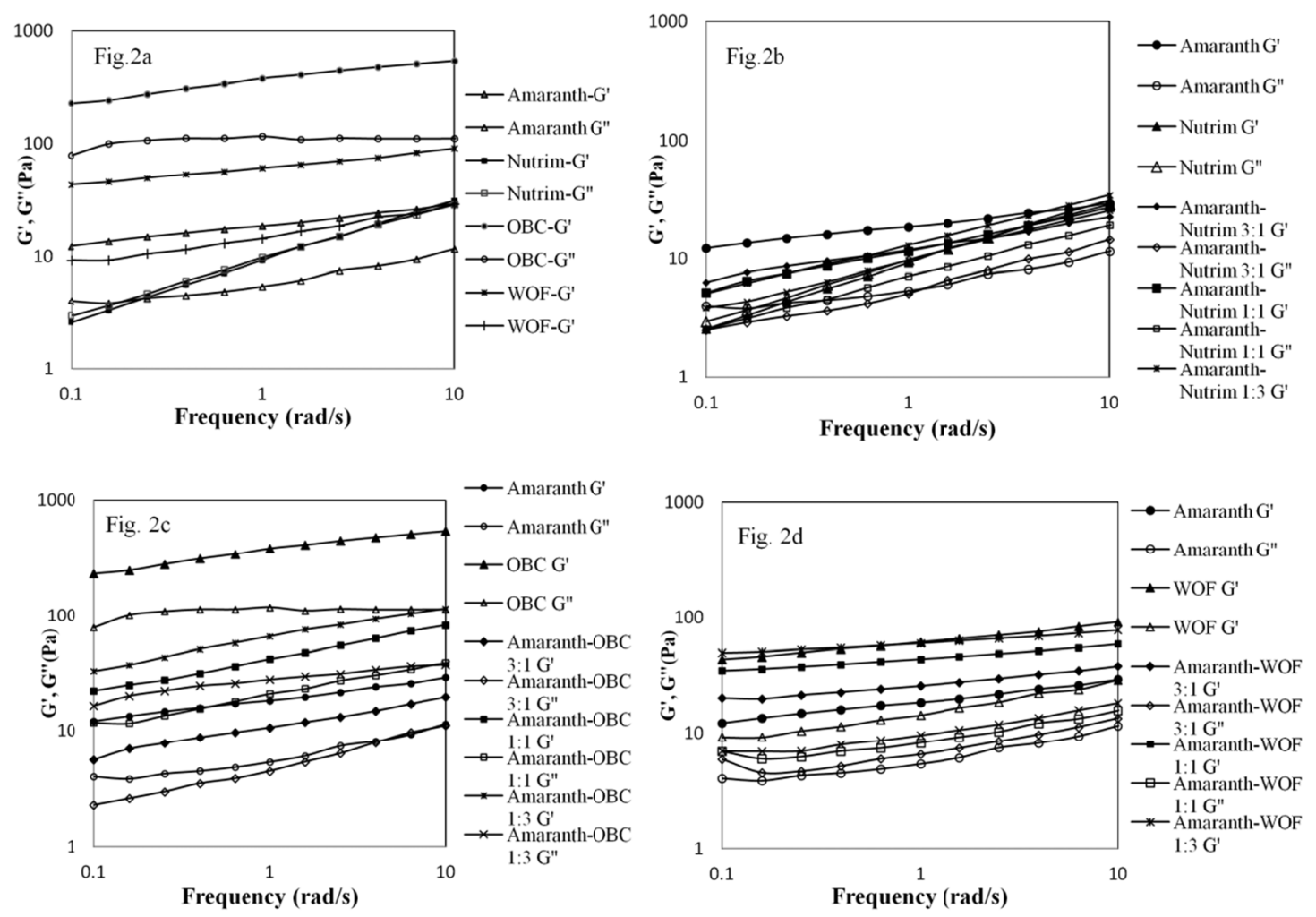

Figure 2. Dynamic viscoelastic properties of amaranth, oat products, and oat-amaranth composites after RVA evaluation

Furthermore, these rheological patterns of the amaranth-oat composites were clearly shown by the tan $\delta$ values (loss modulus $\mathrm{G}^{\prime \prime} /$ storage modulus $\mathrm{G}^{\prime}$ ) (Figure 3). The values of $\tan \delta$ indicate the ratio of energy lost to the amount of energy stored during a test cycle. The phase shift $\delta$ is defined by $\delta=\tan ^{-1}\left(G^{\prime \prime} / G^{\prime}\right)$, which indicates whether a material is solid $\left(\delta=0^{\circ}\right)$, liquid $\left(\delta=90^{\circ}\right)$, or between $\left(0^{\circ}<\delta<90^{\circ}\right)$. Therefore, the values of $\tan \delta$ are from zero to infinity; and $\tan \delta=1$ means $\mathrm{G}^{\prime}=\mathrm{G}^{\prime \prime}, \tan \delta<1$ represents $\mathrm{G}^{\prime}>\mathrm{G}^{\prime \prime}$, and $\tan \delta>1$ indicates $\mathrm{G}^{\prime}<\mathrm{G}^{\prime \prime}$. The $\tan \delta$ has been used for food products to indicate the strong relationship between the viscous behavior and the degree of hydrolysis such as casein (Gravier et al., 2004). The tan $\delta$ values for Nutrim and OBC were slightly decreased with increasing frequency (Figure 3a). Also, the tan $\delta$ values of amaranth-Nutrim 3:1 and 1:1were slightly increased with frequencies while $\tan \delta$ values for amaranth-Nutrim 1:3 almost remained constant with increased frequencies as amaranth (Figure $3 \mathrm{~b}$ ). In contrast, $\tan \delta$ was decreased with the increased frequency for $\mathrm{OBC}$ and its amaranth composites 1:3 (Figure 3c) while $\tan \delta$ was increased with the increased frequency for amaranth and amaranth-OBC composites 3:1 (Figure 3c). It suggested that loss modulus G" of OBC and amaranth-OBC composites 1:3 were decreased suggesting more elastic property that may be contributed to the components and structures of $\mathrm{OBC}$. This enhanced elastic property could provide better shape retention during handling and cooking. No dramatic changes were observed for WOF and amaranth-WOF composites (Figure 3d). It indicated that adding WOF to amaranth had little effect on the viscosity properties of amaranth. 

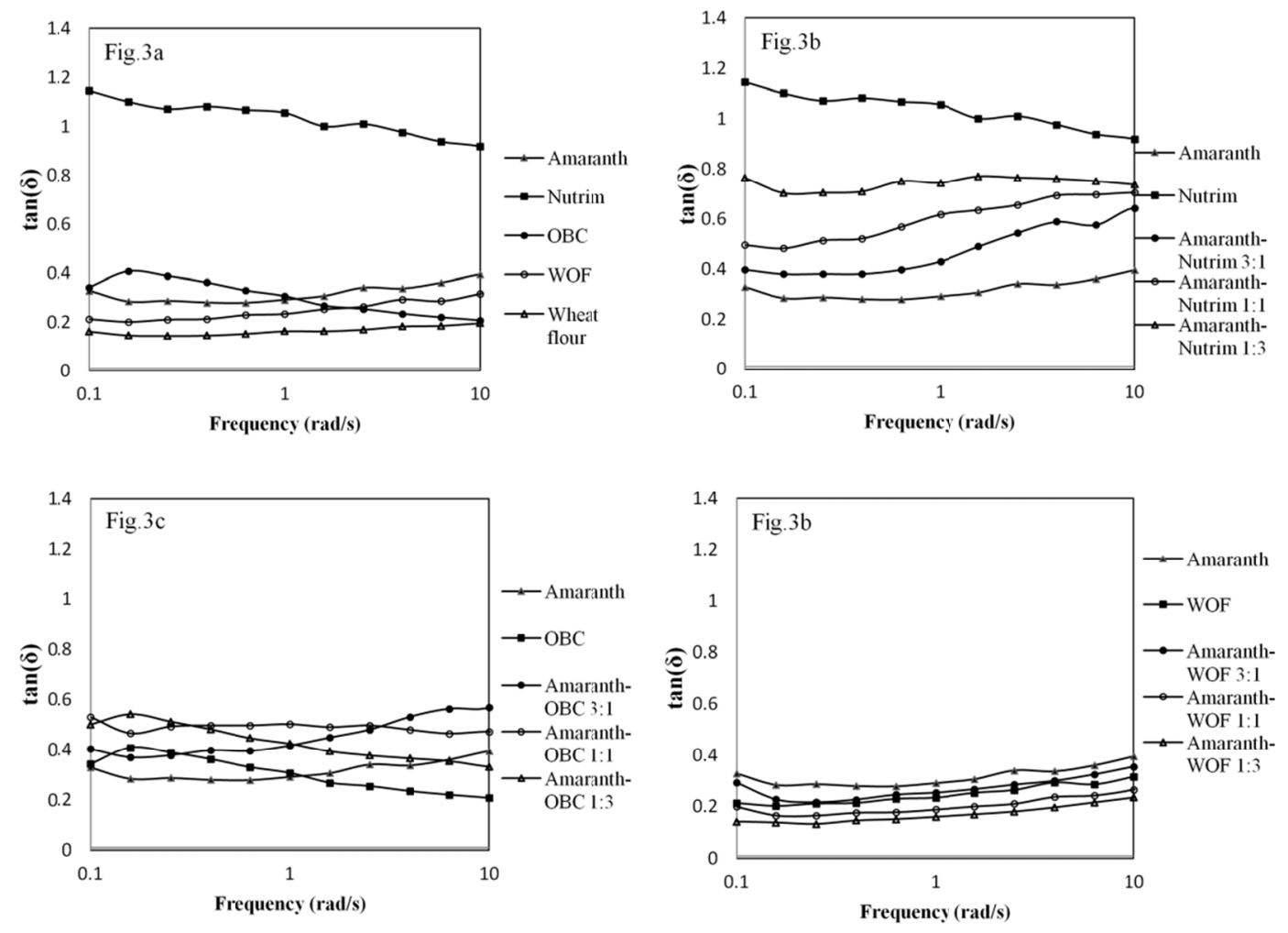

Figure 3. Values of $\tan (\delta)$ versus frequency $(\mathrm{rad} / \mathrm{s})$ for amaranth, oat products, and oat-amaranth composites after RVA evaluation

The apparent viscosity of the samples vs. shear rate was illustrated in Figure 4. Rheological properties of food products, specifically apparent viscosity, have been used as references for predicting their performance during processing (Salvador et al., 2004). Most food processing and mastication occur in a shear rate range of 1 to 100 $\mathrm{s}^{-1}$ (Bloksma, 1988). All of the samples exhibited shear thinning behaviors over the entire measured shear rates at $25{ }^{\circ} \mathrm{C}$. Shear-thinning behavior can be observed in many food materials such as soy, rice, and wheat flour. This type of shear-thinning behavior can be attributed to the disruption of random coil polymers and/or their parallel alignment with flow stream during shearing (Salamone, 1996). OBC seems to have a higher apparent viscosity, followed by WOF while Nutrim had a lower apparent viscosity than OBC and WOF (Figure 4a). Interestingly, Nutrim had slightly lower apparent viscosity than amaranth at the low shear rate, and the apparent viscosities increased gradually with increasing shear rate that were higher than amaranth at high shear rate (Figure 4a). Some prosperity could be attributed by the beta-glucan component of Nutrim with its high WHC. The apparent viscosities were not affected greatly by the addition of Nutrim to amaranth. The apparent viscosities of $\mathrm{OBC}$ and its composites were decreased with the increasing percentages of amaranth, but the large differences between composites were observed for OBC showing a much higher viscosity than amaranth (Figure 4c). The apparent viscosities of Nutrim and WOF composites suggested that those samples could have a similar thickening-effect in food processing (Figure $4 \mathrm{~b} \& \mathrm{~d}$ ). Some properties of amaranth were not affected to a large extent by the addition of oat products. Overall, the apparent viscosities were decreased by increasing amaranth contents indicating by shear thinning trends for all composites. Shear-thinning behavior of a material has several potential advantages in food applications since viscosity can be reduced with the increasing shear rates. This behavior becomes favorable in industrial operations such as mixing and pumping. In addition, it was reported that the polysaccharide solutions in which viscosity decreases rapidly at shear rates are easily and quickly swallowed (Szczesniak \& Farkas, 1962). Hence, the shear-thinning behavior can contribute to a light and nonslimy mouthfeel for food products. Because the experimental conditions we adopted were similar to actual processing situations, all our findings on rheological characteristics could be beneficial for processing and developing amaranth-oat composites for new food applications. 

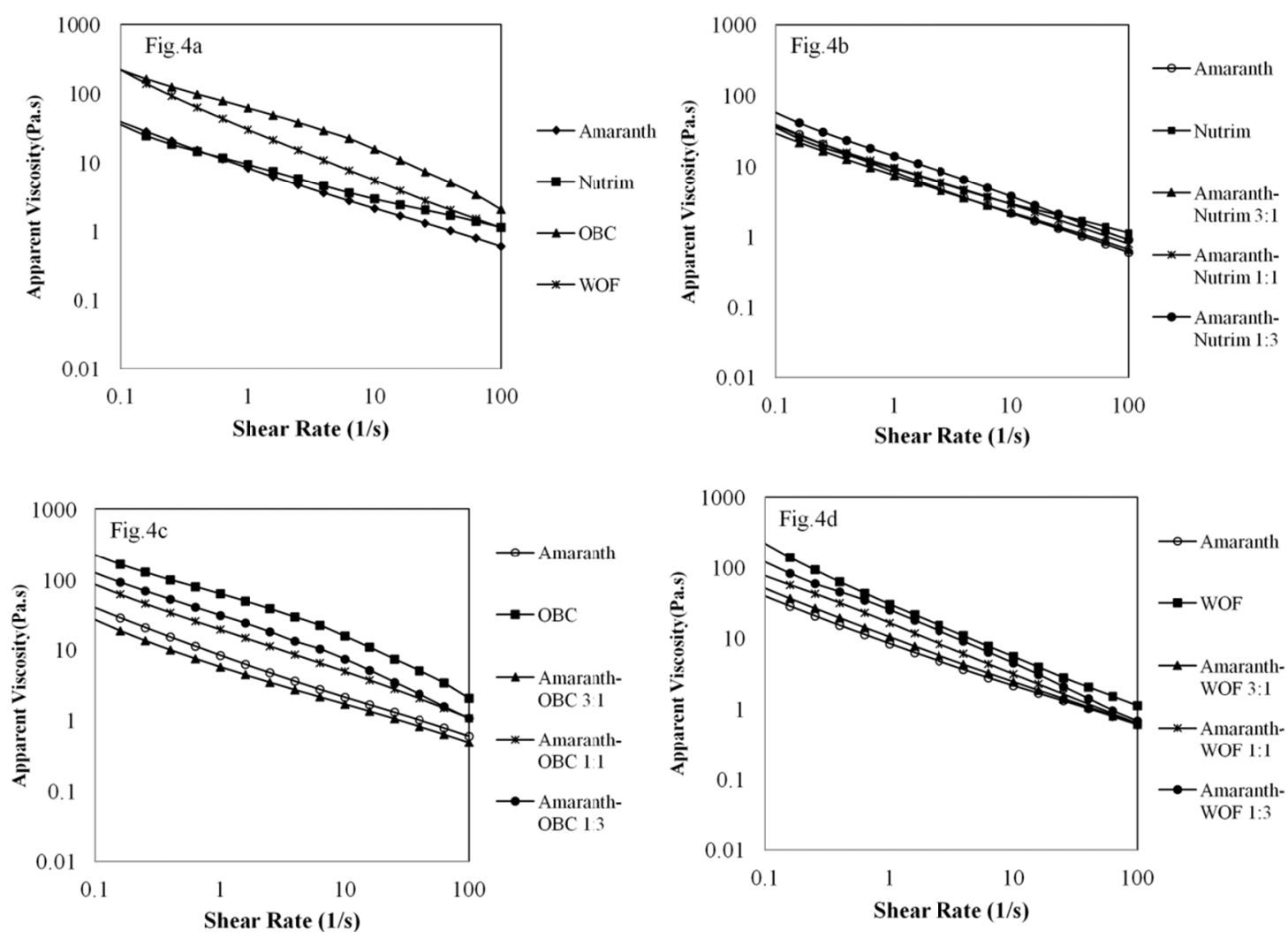

Figure 4. Apparent viscosity versus shear rate plots of amaranth, oat products, and oat-amaranth composites after RVA evaluation

\section{Discussion}

The pasting and rheological properties of amaranth-oat composites prepared by interacting amaranth flour (Salvia hispanica L.) with Nutrim, OBC, WOF, respectively, revealed some useful functional properties and potential nutritional food applications. Amaranth-oat composites were unique because they combined the oat soluble fiber $\beta$-glucan that is beneficial for food texture and coronary heart disease prevention with the health benefits of the gluten free and essential amino acids of amaranth. The amaranth-oat composites maintain the original oat product quality along with the nutritional values of amaranth. Besides the nutritional aspects of the amaranth-oat composites, the composites also have improved water holding capacities, texture, and advantageous viscoelastic qualities. The physical and chemical properties of these innovative amaranth-oat composites could be valuable for developing new functional foods with improved nutritional value and desirable texture qualities for health concerned consumers.

\section{References}

Ade-Omowaye, B. I. O., Taiwo, K. A., Eshtiaghi, N. M., Angersbach A., \& Knorr, D. (2003). Comparative evaluation of the effects of pulsed electric field and freezing on cell membrane permeabilisation and mass transfer during dehydration of red bell peppers. Innovative Food Sci. Emerging Technol, 4, 177-188. http://dx.doi.org/10.1016/S1466-8564(03)00020-1

Ayo, J. A. (2001). The effect of amaranth grain flour on the quality of bread. International Journal of Food Properties, 4, 341-351. http://dx.doi.org/10.1081/JFP-100105198

Bloksma, A. (1988). Rheology of the bread making process. Paper presented at $8^{\text {th }}$ International Cereal and Bread Congress. Lausanne, Switzerland.

Bressani, R., Elias, G. L., \& Garcia-Soto, A. (1989). Limiting amino acids in raw and processed amaranth grain protein from biological tests. Plant foods for human nutrition (Kluwer Academic Publishers), 39, 223-234. http://dx.doi.org/10.1007/BF01091933

Czerwiński, J., Bartnikowska, E., \& Leontowicz, H. (2004). Oat (Avena sativa L.) and amaranth (Amaranthus 
hypochondriacus) meals positively affect plasma lipid profile in rats fed cholesterol-containing diets. $J$. Nutr. Biochem, 15, 622-629. http://dx.doi.org/10.1016/j.jnutbio.2004.06.002

Gallagher, E., Gormley, T. R., \& Arendt, E. K. (2004). Recent advances in the formulation of gluten-free cereal-based products. Trends in Food Science \& Technology, 15, 143-152. http://dx.doi.org/10.1016/j.tifs.2003.09.012

Gravier, N. G., Zaritzky, N. E., \& Califano, A. N. (2004). Viscoelastic behavior of refrigerated and frozen low-moisture Mozzarella cheese. J. Food Science, 9, 123-128.

Guha, M., Zakiuddin, A. S., \& Bhattacharya, S. (1998). Effect of barrel temperature and screw speed on rapid viscoanalyser pasting behaviour of rice extrudate. International Journal of Food Science and Technology, 3, 259-266. http://dx.doi.org/10.1046/j.1365-2621.1998.00189.x

Inglett, G. E., Chen, D., \& Berhow, M. (2011). Influence of jet cooking Prowashonupana barley flour on phenolic composition, antioxidant activities, and viscoelastic properties. Cereal Chemistry, 88, 315-320. http://dx.doi.org/10.1094/CCHEM-10-10-0150

Inglett, G. E. (2011). Low-Carbohydrate Digestible Hydrocolloidal Fiber Compositions. U. S. Patent Number $7,943,766 \mathrm{~B} 2$.

Inglett, G. E. (2000). Soluble hydrocolloid food additives and method of making. U. S. Patent Number $6,060,519$.

Inglett, G. E., Chen, D., Liu, X. S., \& Lee, S. (2014). Pasting and rheological properties of oat products dry-blended with ground chia seeds. LWT-Food Science and Technology, 55, 148-156. http://dx.doi.org/10.1016/j.lwt.2013.07.011

Inglett, G. E., Maneepun, S., \& Vatanasuchart, N. (2000). Evaluation of hydrolyzed oat flour as a replacement for butter and coconut cream in bakery products. Food Science and Technology International, 6, 457-462. http://dx.doi.org/10.1177/108201320000600604

Inglett, G. E., \& Chen, D. (2012). Antioxidant and pasting properties of oat B-glucan hydrocolloids. Food and Nutrition Sciences, 3, 827-835. http://dx.doi.org/10.4236/fns.2012.36111

Kaufmann, C. S., \& Weber, L. E. (1990). Grain amaranth. In J. Janick \& J. E. Simon (Eds.), Advances in New Crops (pp. 127-139). Timber Press, Portland, Oregon, USA.

Kim, S., Inglett, G. E., \& Liu, S. X. (2008). Content and molecular weight distribution of oat $\beta$-glucan in oatrim, nutrim, and C-trim products. Cereal Chemistry, 85, 701-705. http://dx.doi.org/10.1094/CCHEM-85-5-0701

Klopfenstein, C. F. (1988). The role of cereal beta-glucans in nutrition and health. Cereal Food World, 33, 865-869.

Lai, H. M., \& Cheng, H. H. (2004). Properties of pregelatinized rice flour made by hot air or gum puffing. International Journal of Food Science and Technology, 39, 201-212. http://dx.doi.org/10.1046/j.0950-5423.2003.00761.x

Lai, L. S., \& Liao, C. L. (2002). Steady and dynamic shear rheological properties of starch and decolorized Hsian-tsao leaf gum composite systems. Cereal Chemistry, 79, 58-63. http://dx.doi.org/10.1094/CCHEM.2002.79.1.58

Lee, M. H., Baek, M. H., Cha, D. S., Park, H. J., \& Lim, S. T. (2002). Freeze-thaw stabilization of sweet potato starch gel by polysaccharide gums. Food Hydrocolloids, 16, 345-352. http://dx.doi.org/10.1016/S0268-005X(01)00107-2

Lee, S., \& Inglett, G. E. (2006). Rheological and Physical evaluation of jet-cooked oat bran in low calorie cookies. International Journal of Food Science and Technology, 41, 553-559. $\mathrm{http}: / / \mathrm{dx}$. doi.org/10.1111/j.1365-2621.2005.01105.x

Lee, S., Inglett, G. E., \& Carriere, C. J. (2004). Effect of nutrim oat bran and flaxseed on rheological properties of cakes. Cereal Chemistry, 81, 637-642. http://dx.doi.org/10.1094/CCHEM.2004.81.5.637

Lee, S., Inglett, G. E., Palmquist, D., \& Warner, K. (2009). Flavor and Texture Attributes of Foods Containing $\beta$-Glucan-Rich Hydrocolloids from Oats. LWT - Food Science and Technology, 42, 350-357. http://dx.doi.org/10.1016/j.lwt.2008.04.004

Lee, S., Warner, K., \& Inglett, G. E. (2005). Rheological properties and baking performance of new oat $\beta$-glucan-rich hydrocolloids. Journal of Agricultural and Food Chemistry, 53, 9805-9809. 
http://dx.doi.org/10.1021/jf051368o

Macvean, D., Pöll. (1997). Chapter 8: Ethnobotany. In J. A. Vozzo (Ed.) Tropical Tree Seed Manual, USDA Forest Service.

Madhujith, T., \& Shahidi, F. (2007). Antioxidative and antiproliferative properties of selected barley (Hordeum vulgare L.) cultivars and their potential for inhibition of low-density lipoprotein (LDL) cholesterol oxidation. Journal of Agricutlural and Food Chemistry, 55, 5018-5024.

Maneepun, S., Boonpunt, T., \& Inglett, G. E. (1998). Sensory and nutritional evaluation of co-processed Nutrim OB and soy flour in Thai dishes. In: 216th ACS National Meeting. AGFD-099. Boston.

Martirosyan, D. M., Miroshnichenko, L. A., Kulakova, S. N., Pogojeva, A. V., \& Zoloedov, V. I. (2007). Amaranth oil application for coronary heart disease and hypertension. Lipids Health Dis., 6, 1. http://dx.doi.org/10.1186/1476-511X-6-1

Myers, L. R., \& Putnam, H. D. (1988). Growing Grain Amaranth as a Specialty Crop. In Crop Systems. University of Minnesota. FS-03458-GO.

Pisarikova, B., Peterka, J., Trčková, M., Moudrý, J., Zralý, Z., \& Herzig, I. (2006). Chemical composition of the above-ground biomass of Amaranthus cruentus and A. hypochondriacus. Acta Veterinaria Brno, 75, 33-138. http://dx.doi.org/10.2754/avb200675010133

Rojas, J. A., Rosell, C. M., \& Benedito de Barber, C. (1999). Pasting properties of different wheat $\begin{array}{lllll}\text { flour-hydrocolloid } \quad \text { systems. } & \text { Food } & \text { Hydrocolloids, } & \text { 13, } & \text { 27-33. }\end{array}$ http://dx.doi.org/10.1016/S0268-005X(98)00066-6

Rosell, C. M., Rojas, J. A., \& Benedito de Barber, C. (2001). Influence of hydrocolloids on dough rheology and bread quality. Food Hydrocolloids, 15, 75-81. http://dx.doi.org/10.1016/S0268-005X(00)00054-0

Salamone, J. C. (1996). Polymeric Materials Encyclopedia. CRC Press, Boca Raton, FL.

Salvador, A., Sanz, T., \& Fiszman, S. (2002). Effect of corn flour, salt, and leavening on the texture of fried, battered squid rings. J. Food Science., 76, 730-733. http://dx.doi.org/10.1111/j.1365-2621.2002.tb10667.x

SAS Institute INC. (1999). The SAS ${ }^{\circledR}$ system for Windows ${ }^{\circledR}$, version 8e. Cary, NC.

Szczesniak, A. S., \& Farkas E, (1962). Objective characterization of the mouthfeel of gum solutions. J. Food Sci., 27, 381-385. http://dx.doi.org/10.1111/j.1365-2621.1962.tb00112.x

University of Maryland Medical Center. (2013). Retrieved from http://umm.edu/health/medical/altmed/supplement/vitamin-k\#ixzz33t70aIeT

University of Wisconsin \& University of Minnesota. (2011). Amaranth - Alternative Field Crops Manual.

USDA Nutrient Database. (2014). http://ndb.nal.usda.gov/ndb/foods/show/6238

University of Maryland Medical Center. (2013). Retrieved from http://umm.edu/health/medical/altmed/supplement/vitamin-k\#ixzz33t70aIeT

Vaikousi, H., Biliaderis, C. G., \& Izydorczyk, M. S. (2004). Solution flow behavior and gelling properties of water-soluble barley $(1 \rightarrow 3,1 \rightarrow 4)$ - $\beta$-glucans varying in molecular size. Journal of Cereal Science, 39 , 119-137. http://dx.doi.org/10.1016/j.jcs.2003.09.001

Warner, K., \& Inglett, G. E. (1998). Flavor and texture characteristics of foods containing nutrim oat bran hydrocolloid. In: 216th ACS National Meeting. AGFD-97. Boston.

\section{Copyrights}

Copyright for this article is retained by the author(s), with first publication rights granted to the journal.

This is an open-access article distributed under the terms and conditions of the Creative Commons Attribution license (http://creativecommons.org/licenses/by/3.0/). 